\title{
PENINGKATAN HASIL BELAJAR IPS DENGAN MENGGUNAKAN METODE PEMBELAJARAN TALKING STICK UNTUK SEKOLAH DASAR
}

\author{
Florentina Jenanu, Arifin Maksum, Ika Lestari \\ e-mail: ikalestarisartomo@gmail.com \\ PGSD FIP UNJ
}

\begin{abstract}
Abstrak: Mata pelajaran IPS berkaitan dengan kehidupan bersama manusia. IPS membekali siswa untuk mengembangkan penalarannya di samping aspek nilai dan moral. Namun, kendala yang ada IPS lebih bersifat hapalan sehingga pengetahuan dan informasi yang diterima siswa terbatas produk hapalan. Sifat materi pelajaran IPS tersebut membawa konsekuensi terhadap proses belajar dan pembelajaran yang didominasi oleh pendekatan ekspositoris, terutama guru menggunakan metode ceramah. Penelitian ini ingin meningkatkan hasil belajar IPS dengan penggunaan metode talking stick. Penelitian ini dilaksanakan di kelas V SDN 09 Pagi Rawamangun Jakarta Timur, Juli - September 2014. Metode penelitian dengan menggunakan Penelitian Tindakan Kelas dari Kemmis dan Mc Taggart. Hasil penelitian menunjukkan terjadi peningkatan hasil belajar IPS dengan penggunaan metode talking stick.
\end{abstract}

Kata kunci: Ilmu pengetahuan sosial, talking stick, hasil belajar

\section{IMPROVING THE STUDENT'S LEARNING ACHIEVEMENT IN SOCIAL SCIENCE APPLYING TALKING STICK METHOD IN ELEMENTARY SCHOOL.}

\begin{abstract}
Social science is closely related to the human life and social Science helps the students to develop his/her logic beside value and morality. However social science tend to be recital and the information and the knowledge the student obtains are verbal products. The social science characteristics make the instructional process is dominated by expository approach and the teacher mostly uses oral method. This research aimed at improving the student's learning achievement at Government Elementary School 9, Grade V, in Rawamangun, East Jakarta, by applying talking stick method. The research conducted as from July through September 2014, employed classroom action research with Kemmis and Taggard's model. The finding indicated talking stick method is effective to improve the student's learning achievement.
\end{abstract}

Social science, talking stick method, learning achievement

\section{PENDAHULUAN}

Sistem pendidikan sebagai pranata sosial yang kuat dan berwibawa bertugas memberdayakan semua Warga Negara Indonesia agar berkembang menjadi manusia yang berkualitas sehingga mampu dan proaktif dalam menjawab tantangan zaman yang selalu berubah.

Upaya peningkatan mutu pendidikan di Indonesia, dalam usaha untuk mencerdaskan kehidupan bangsa, harus dilakukan secara menyeluruh mencakup pengembangan dimensi manusia Indonesia seutuhnya agar mampu bersaing dengan mutu pendidikan negara-negara maju lainnya. Dengan melihat tujuan pendidikan nasional di Indonesia, nyatalah bahwa guru merupakan bagian penting untuk menciptakan sumber daya manusia yang berkualitas. Untuk menciptakan sumber daya manusia yang berkualitas tersebut diperlukan proses belajar pembelajaran yang efektif. Dengan belajar, manusia dapat menguasai ilmu pengetahuan serta mampu bersinergi dengan tuntutan perkembangan zaman. Dikatakan demikian karena kemajuan di berbagai bidang kehidupan sangat membutuhkan tenaga yang profesional, cakap dan terampil dalam menghadapi permasalahan hidup, dan hal ini diperoleh melalui belajar.

Sekolah mengemban tugas untuk membentuk konsep berpikir siswa sehingga mampu mengembangkan kreativitas dan segenap kemampuan yang dimiliki sebagai bekal untuk dapat memecahkan setiap permasalahan yang dihadapi dalam kehidupan sehari-hari, selain itu juga untuk membentuk siswa yang bertakwa dan bertanggung jawab atas dirinya sendiri dan lingkungan hidupnya. Dengan demikian 
peran sekolah sangatlah penting.

Dalam kehidupan bermasyarakat, Ilmu Pengetahuan Sosial (IPS) sangat penting perannya. Oleh karena itu, belajar IPS selayaknya merupakan kebutuhan dan menjadikan kegiatan belajar pembelajaran yang menyenangkan.

Tujuan mempelajari IPS adalah agar siswa memiliki kemampuan di bidang sosial. Penanaman konsep IPS sangat diperlukan pada siswa, karena hal itu akan dapat diterapkan dalam kehidupan sehari-hari. Untuk pembelajaran IPS akan lebih baik bila dimulai penyajiannya dari bentuk yang nyata yaitu dimulai dengan pengalaman langsung atau pengalaman konnkret dan menuju kepada konsep yang lebih abstrak.

Mata Pelajaran Ilmu Pengetahuan Sosial (IPS) merupakan kajian antar disiplin, IPS mengkaji seperangkat peristiwa, fakta, konsep, dan generalisasi yang berkaitan dengan isu sosial. Melalui mata pelajaran IPS, siswa diarahkan untuk dapat menjadi warga Negara Indonesia yang demokratis, dan bertanggung jawab, serta warga dunia yang cinta damai.

Selain melihat ruang lingkup Ilmu Pengetahuan Sosial yang mengarah pada segala hal yang berkaitan dengan kehidupan berasama dengan manusia, maka terdapat beberapa indikator mata pelajaran Ilmu Pengetahuan Sosial yang hendak dicapai dalam proses belajar mengajar di sekolah. Tentunya, yang menjadi sasaran utama dalam indikator tersebut berkisar pada hasil yang diperoleh anak setelah melalui tahapan pembelajaran IPS.

Hasil belajar IPS adalah upaya memberikan nilai terhadap kegiatan belajar mengajar yang dilakukan oleh siswa dan guru dalam mencapai tujuan pengajaran. Dalam penilaian ini akan dilihat sejauh mana keefektifan dan efesiensinya dalam mencapai tujuan pengajaran serta sejauh mana perubahan tingkah laku yang dicapai siswa.

Penelitian ini melihat persoalan di lapangan terkait dengan mata pelajaran IPS di SDN Rawamangun 09 Pagi Jakarta Timur. Permasalahan yang timbul di SDN Rawamangun 09 Pagi Jakarta Timur yaitu guru kurang mempunyai bekal yang memadai untuk memberikan pembelajaran IPS. Terkadang guru hanya menekankan pada bobot materi sehingga siswa hanya dituntut untuk membaca atau mendengarkan ceramah dari guru. Pemakaian metode dan mediapun belum banyak dikuasai guru serta pembelajaran IPS banyak memuat materi sosial dan bersifat hafalan sehingga pengetahuan dan informasi yang diterima siswa terbatas produk hafalan. Sifat materi pelajaran IPS tersebut membawa konsekuensi terhadap pros- es belajar dan pembelajaran yang didominasi oleh pendekatan ekspositori, terutama guru menggunakan metode ceramah terjadi dialog imperatif sehingga hasil belajar yang dicapai oleh siswa tidak optimal.

Rendahnya hasil belajar siswa ini diperoleh dari target presentase pencapaian KKM yang hanya mencapai 58\% dari 28 siswa yang terdiri dari 14 siswa laki-laki dan 14 siswa perempuan,yaitu 16 siswa yang memperoleh nilai 65-85. Adapun target pencapaian skor rata-rata KKM di SDN 09 Pagi Rawamangun Jakarta Timur dengan ketercapaian KKM 65\%.

Salah satu penyebab rendahnya hasil nilai ulangan siswa adalah kurang optimalnya kualitas pembelajaran di dalam kelas. IPS sebagai salah satu bidang studi yang memiliki tujuan membekali siswa untuk mengembangkan penalarannya di samping aspek nilai dan moral, banyak memuat materi sosial dan bersifat hafalan sehingga pengetahuan dan informasi yang diterima siswa terbatas produk hafalan. Sifat materi pelajaran IPS tersebut membawa konsekuensi terhadap proses belajar dan pembelajaran yang didominasi oleh pendekatan ekspositoris, terutama guru menggunakan metode ceramah terjadi dialog imperatif. Padahal, dalam proses belajar pembelajaran keterlibatan siswa harus secara totalitas, artinya melibatkan pikiran, penglihatan, pendengaran dan psikomotor (keterampilan, salah satunya sambil menulis). Jadi, dalam proses belajar pembelajaran, seorang guru mengajak siswa untuk mendengarkan, menyediakan media yang dapat dilihat, memberi kesempatan untuk menulis dan mengajukan pertanyaan atau tanggapan sehingga terjadi dialog kreatif yang menunjukkan proses belajar pembelajaran yang kooperatif. Situasi belajar seperti ini dapat tercipta melalui penggunaan model pembelajaran kooperatif.

Metode pembelajaran talking Stick sebagaimana dimaksudkan, dalam proses belajar pembelajaran di kelas berorientasi pada terciptanya kondisi belajar melalui permainan tongkat yang diberikan dari satu siswa kepada siswa yang lainnya pada saat guru menjelaskan materi pelajaran dan selanjutnya mengajukan pertanyaan. Saat guru selesai mengajukan pertanyaan, maka siswa yang sedang memegang tongkat itulah yang memperoleh kesempatan untuk menjawab pertanyaan tersebut. Tipe ini berguna untuk menguji kesiapan siswa dan melatih membaca dan memahami dengan cepat serta lebih giat dalam belajar. Model pembelajaran ini membuat siswa ceria, senang, dan melatih mental untuk siap pada kondisi dan situasi apapun.

Langkah-langkah Penerapan Model Pembelajaran Talking Stick: (1) guru menyiapkan sebuah tongkat 
yang kira-kira panjangnya $20 \mathrm{~cm}$; (2) guru membagi siswa menjadi beberapa kelompok dengan anggota 4-6 siswa; (3) guru menyampaikan materi pokok yang akan dipelajari; (4) guru memberikan kesempatan para kelompok untuk membaca dan mempelajari materi pelajaran; (5) siswa berdiskusi membahas masalah yang terdapat di dalam wacana; (6) setelah siswa selesai membaca materi pelajaran dan mempelajari isinya, guru mempersilahkan siswa untuk menutup isi bacaanl; (7) guru mengambil tongkat dan memberikan kepada salah satu siswa, setelah itu guru memberikan pertanyaan dan siswa yang memegang tongkat tersebut harus menjawabnya, demikian sampai sebagian besar siswa mendapat bagian untuk menjawab setiap pertanyaan dari guru; (8) guru bersama siswa menyimpulkan materi yang telah dipelajari; (9) guru memberikan evaluasi/ penilaian; dan (10) guru menutup pembelajaran.

Dengan demikian, maka rumusan masalah dalam penelitian ini yaitu berusaha mencari jawaban atas pertanyaan: "Bagaimana penggunaan model pembelajaran kooperatif tipe Talking Stick dapat meningkatkan hasil belajar IPS siswa kelas V SDN 09 Pagi Rawamangun Jakarta Timur?"

\section{METODE PENELITIAN}

Penelitian ini dilaksanakan pada kelas V SDN 09 Pagi Rawamangun Jakarta Timur. Waktu penelitian dimulai dari bulan April hingga September 2014. Jumlah siswa kelas V SDN 09 Pagi Rawamangun Pulogadung, Jakarta Timur berjumlah 37 siswa, terdiri dari 19 siswa laki-laki dan 18 siswa perempuan.

Metode penelitian ini menggunakan penelitian tindakan kelas dari Kemmis dan Mc. Taggart. Rancangan siklus penelitian ini memiliki empat tahapan kegiatan pada setiap siklusnya yaitu perencanaan, tindakan, pengamatan, dan refleksi.

Model PTK dari Kemmis dan McTaggart adalah suatu siklus spiral yang terdiri dari perencanaan, pelaksanaan tindakan, pengamatan (observasi), dan refleksi, yang selanjutnya mungkin diikuti dengan siklus spiral berikutnya.

Subjek dalam penelitian ini adalah siswa kelas V SDN Rawamangun di wilayah Jakarta Timur yaitu SDN 9, 10, dan 11 Rawamangun Jakarta Timur. PartisIPSn dalam penelitian ini yaitu Kepala Sekolah dan guru kelas V di SDN 9, 10, dan 11 Rawamangun Jakarta Timur tempat penelitian dilakukan.

Peran peneliti dalam penelitian ini sebagai pemimpin perencanaan, pelaksana tindakan sekaligus pembuat laporan. Posisi peneliti dalam penelitian ini sebagai guru yang mengajarkan materi IPS dan melakukan proses belajar dan pembelajaran di kelas sesuai fokus penelitian.

Hasil tindakan yang diharapkan yaitu adanya perubahan pada peningkatan hasil belajar IPS siswa, dan perubahan itu cenderung positif dari waktu ke waktu. Tindakan akan dikatakan berhasil apabila pada setiap siklus terjadi peningkatan hasil belajar pada siswa dan telah menguasai indikator pembelajaran yang telah dirumuskan dalam RPP. Kemudian, dari hasil evaluasi belajar diharapkan $80 \%$ siswa telah mencapai nilai rata-rata skor 75 melebihi KKM yang ditentukan sekolah yaitu 60 . Sedangkan, 20\% siswa yang masih berada di bawah KKM akan diberikan remedial oleh peneliti.

Data penelitian yang dihasilkan dibedakan menjadi dua jenis yaitu data pemantauan tindakan dan data penelitian yang berisi tentang hasil belajar IPS. Sedangkan sumber data dalam penelitian ini yaitu seluruh siswa kelas V SD di wilayah Jakarta Timur sesuai dengan tempat penelitian yang dipilih.

Penelitian ini menggunakan dua instrumen penelitian yaitu tes dan nontes. Instrument tes untuk mengumpulkan data hasil belajar siswa sedangkan nontes untuk menjaring data pemantau tindakan yaitu data proses pembelajaran selama tindakan diberikan dengan menggunakan lembar pengamatan. Teknik pengumpulan data pada penelitian adalah observasi, tes, dan dokumentasi.

\section{HASIL DAN PEMBAHASAN}

\section{A. Hasil Penelitian}

Peran peneliti dalam penelitian tindakan kelas ini bertindak sebagai pemimpin, perencanaan dan pelaksanaan tindakan di kelas. Penelitian berlangsung selama dua siklus dan setiap siklus terdiri dari dua kali pertemuan. Alokasi waktu setiap pertemuan adalah $5 \times 35$ menit. Pelaksanaan setiap siklus melalui tahap perencanaan, pelaksanaan, pengamatan (observasi) dan refleksi.

Sebelum melaksanakan tindakan siklus I, peneliti membuat Rencana Pelaksanaan Pembelajaran (RPP), yang mengacu pada kurikulum 2013 yang di dalamnnya mencakup rangkaian kegiatan pembelajaran yang berorentasi pada metode kooperatif tipe talking stick dengan memperhatikan kemampuan dasar siswa terhadap materi yang akan disampaikan.

Dalam perencanaan tindakan, peneliti mempersiapkan hal-hal sebagai berikut: (1) rencana pelaksanaan pembelajaran; (2) menyiapkan media tongkat yang dibuat menarik dan aman; (3) 
menyiapkan LKS yang akan di bagikan kepada siswa; (4) menyiapkan pertanyaan saat talking stick berlangsung; (5) menyiapkan hadiah seperti penghapus dan pensil kemenangan sebagai apersepsi bagi siswa yang menjawab benar dan aktif; dan (6) menyiapkan instrumen pengamatan.

Pengamat atau observer dalam mengamati pelaksanaan pembelajaran di kelas dilengkapi dengan kamera untuk mendokumentasikan kegiatan pembelajaran.

Adapun langkah-langkah pelaksanaan tindakan pada siklus ini sesuai dengan yang direncanakan dalam skenario pembelajaran. Tindakan yang dilakukan berdasarkan hasil kesepakatan yang telah diputuskan bersama dengan kolaborator, yaitu materi mengenai sehat itu penting dengan menggunakan metode pembelajaran talking stick. Dalam penerapan tindakan ini peneliti melaksanakan langkah-langkah pembelajaran sesuai skenario mengenai sehat itu penting.

Pengamatan atau observasi dilaksanakan pada saat pelaksanaan tindakan kelas oleh observer dengan mengunakan panduan instrument pemantau tindakan yang berisi 45 butir pernyataan yang terdiri dari 20 butir pernyataan untuk guru dan 25 butir pernyaatan untuk siswa. Dalam hal ini observer yang ditunjuk adalah teman sejawat. Selain menggunakan instrumen pemantau tindakan yang di nilai oleh observer pada saat pembelajaran berlangsung observer membuat catatan lapangan yang berisi kekurangan dan kelebihan pada saat proses pembelajaran dengan mengunakan metode kooperatif tipe talking stick melalui pengamatan terhadap aktifitas guru dan aktifiats siswa dalam pembelajaran. Berdasarkan hasil pengamatan pada siklus pertama dapat di lihat dalam tabel 1 dan 2 .

Tabel 1. Hasil Temuan Observer pada Pemantauan Tindakan Guru Siklus I

\begin{tabular}{|c|l|}
\hline NO. & \multicolumn{1}{|c|}{ HASIL PERTEMUAN } \\
\hline 1 & $\begin{array}{l}\text { Guru kurang memperhatikan kesiapan siswa dalam } \\
\text { melaksanakan pembelajaran dengan model kooperatif } \\
\text { tipe talking stick sehingga pelaksanaan pembelajaran } \\
\text { kurang tertib }\end{array}$ \\
\hline 2 & $\begin{array}{l}\text { Guru belum menyampaikan prosedur pelaksanaan ko- } \\
\text { operatif tipe talking stick dengan jelas, sehingga siswa } \\
\text { kebingungan cara melaksanakannya. }\end{array}$ \\
\hline 3 & $\begin{array}{l}\text { Guru kurang menggali kemampuan yang telah dimiliki } \\
\text { oleh siswa tentang sehat itu penting }\end{array}$ \\
\hline 4 & $\begin{array}{l}\text { Guru tidak memberikan pertanyaan kepada siswa lain, } \\
\text { jika siswa yang terkena tongkat tidak dapat menjawab. }\end{array}$ \\
\hline 5 & $\begin{array}{l}\text { Guru tidak melakuan refleksi saat menutup pelajaran } \\
\text { atas pelaksanaan pembelajaran dengan menggunakan } \\
\text { model koperatif tipe talking stick. }\end{array}$ \\
\hline
\end{tabular}

Tabel 2. Hasil Temuan Observer Pada Pemantauan Tindakan Siswa Siklus I

\begin{tabular}{|c|l|}
\hline NO. & \multicolumn{1}{|c|}{ HASIL TEMUAN } \\
\hline 1 & $\begin{array}{l}\text { Siswa belum menerima informasi tentang tujuan pem- } \\
\text { belajaran dengan baik. }\end{array}$ \\
\hline 2 & $\begin{array}{l}\text { Siswa belum menerima informasi prosedur pelaksa- } \\
\text { naan pembelajaran dengan model kooperatif talking } \\
\text { stick }\end{array}$ \\
\hline 3 & $\begin{array}{l}\text { Siswa belum mampu menyebutkan hal-hal yang ber- } \\
\text { hubungan dengan sehat itu penting dengan benar }\end{array}$ \\
\hline 4 & $\begin{array}{l}\text { Siswa belum dapat mengaitkan pelajaran yang akan } \\
\text { dilaksanakan dengan materi sebelumnnya. }\end{array}$ \\
\hline 5 & $\begin{array}{l}\text { Siswa kurang menanyakan hal-hal yang tidak dimen- } \\
\text { gerti tentang materi yang disampaikan. }\end{array}$ \\
\hline 6 & $\begin{array}{l}\text { Siswa belum melakukan refleksi atas pelaksanaan } \\
\text { pembelajaran bersama guru }\end{array}$ \\
\hline 7 & $\begin{array}{l}\text { Siswa belum dapat menyelesaikan LKS sesuai waktu } \\
\text { yang ditetapkan. }\end{array}$ \\
\hline 8 & $\begin{array}{l}\text { Siswa tidak membantu menjawab pertanyaan kepada } \\
\text { teman yang terkena tongkat yang tidak bisa menjawab. }\end{array}$ \\
\hline
\end{tabular}

Hasil pengamatan dan catatan lapangan yang diperoleh kemudian dirangkum dan diskusikan oleh peneliti dan observer. Hasil diskusi ini menjadi masukkan untuk perbaikan yang akan dilakukan pada siklus berikutnya. Hal ini dilakukan agar kekurangan dan kelemahan pada siklus pertama dapat diperbaiki pada siklus berikutnya. Dengan demikian kemampuan belajar siswa akan lebih baik dan lebih meningkat dari kemampuan belajar sebelumnya.

Sebagai dasar bahwa pada siklus ini masih belum maksimal dapat dilihat dari perolehan nilai siswa. Dari hasil temuan, perolehan hasil belajar kognitif masih kurang dari 85\% dari siswa yang mendapat nilai $\geq 75$, yaitu $70 \%$ dengan rata-rata nilai 79,52.

Sama halnya pada siklus I, observer melakukan observasi pada siklus II dengan dibantu oleh lembar pengamatan yang berisi 20 butir pertanyaan untuk guru dan 25 butir pernyataan untuk siswa dengan tujuan untuk mengetahui sejauh mana kegunaan metode pembelajaran talking stick dalam proses pembelajaran untuk meningkatkan hasil belajar siswa.

Kemudian observer juga mengamati kegiatan selama berlangsungnya pembelajaran yang kemudian hasilnya dituangkan dalam bentuk catatan dalam lapangan. Adapun temuan observer pada siklus II jauh lebih meningkat dari siklus I, hal ini dapat dibuktikan bahwa hanya 1 indikator pemantau tindakan guru yang tidak dilaksanakan, guru menyampaikan prosedur pelaksanaan pembelajaran dengan metode kooperatif tipe talking stick. Hal ini tidak dapat dilakukan karena siswa sudah memahami prosedur pelaksanaan pembelajaran yang akan dilaksanakan. 
Begitu pula halnya dengan pemantauan tindakan siswa terdapat 2 indikator pernyataan yang tidak dilakukan yaitu siswa tidak menerima informasi prosedur pelaksanaan pembelajaran dengan talking stick dan siswa masih belum dapat tepat waktu mengumpulkan LKS yang diinstruksikan oleh guru.

Hasil belajar kognitif sudah mengalami peningkatan, dari data yang diperoleh pada siklus I sebanyak 26 siswa atau hanya 70\% dari jumlah siswa yang baru mencapai KKM, tetapi setelah melakukan siklus II diperoleh sekitar 35 siswa atau 95\% dari jumlah seluruh siswa kelas V yang mencapai nilai KKM. Selain itu nilai rata-rata hasil belajar kognitif IPS siswa meningkat, pada siklus I hasil belajar IPS mencapai rata-rata 79,59 namun setelah melakukan siklus II meningkat menjadi 84,59 .

\section{B. Pembahasan}

Berdasarkan analisis data hasil tindakan siklus I dan II terlihat adanya peningkatan dari semua data yang diambil. Data siklus I diperoleh 70\% siswa mencapai nilai KKM, kemudian siklus II menjadi 95\%. Data hasil nilai rata-rata dari siklus I diperoleh 79,52 kemudian siklus II menjadi 84,59. Jadi besar perubahan dari siklus I ke siklus II untuk meningkatkan hasil belajar siswa sebesar $25 \%$.

Siklus II lebih difokuskan untuk memperbaiki setiap kekurangan yang ada pada siklus I. Berdasarkan hasil penelitian maka yang menjadi catatan penting untuk dapat dijadikan bahan pertimbangan pada pelaksanaan tindakan kelas pada siklus II ini adalah masih kurangnya penguasaan kelas oleh guru, sehingga sebagian siswa belum mencapai hasil yang diharapkan diakibatkan siswa-siswa tidak fokus pada materi yang sedang dipelajari maupun pada model pembelajaran talking stick yang digunakan. Maka dari itu peneliti merencanakan tindakan berikutnya. Adapun perencanaan tersebut antara lain: (1) menyiapkan rencana pelaksanaan pembelajaran, (2) menyiapkan media pembelajaran yang sesuai karakteristik anak, (3) menyiapkan instrumen pemantau tindakan, (4) menyiapkan catatan lapangan, (5) menyiapkan tongkat dan hadiah berupa "penghapus dan pensil", dan (6) menyiapkan kamera untuk mendokumentasikan gambar saat dilaksanakannya tindakan.

Pada siklus II peneliti melakukan refleksi atas temuan observer agar berbagai kekurangan yang terdapat pada siklus I tidak terdapat lagi pada siklus II. Peneliti sudah melakukan perbaikan terhadap kekurangan yang ada pada siklus I seperti memperbaiki prosedur, media, pendalaman materi dan langkah-langkah pelaksanaan pembelajaran dengan metode talking stick sehingga perolehan nilai siswa pada siklus II ini mencapai kenaikan yang signifikan. Selain itu, siswa sudah mulai mengenali talking stick sehingga kesiapan belajar yang dialami siswa sudah semakin baik dan hasil refleksi yang diberikan di setiap akhir siklus telah membawa peningkatan dalam hasil belajar.

Selanjutnya, pada siklus II penyebab masalah dari rendahnya hasil belajar seperti instruksi yang diberikan oleh guru dalam pelaksanaan talking stick sudah dapat dimengerti oleh siswa. Siswa sudah mulai mengenal dengan benar mengenai metode kooperatif talking stick tersebut sehingga mengerti manfaatnya dan senang serta antusias saat melakukannya. Selain itu, pada saat proses pembelajaran, pada siklus II siswa sudah mulai tertib dan memperhatikan gambar dengan baik apalagi setelah mengetahui bahwa diakhir pelajaran diberikan hadiah. Siswa sudah mulai berani bertanya hal-hal yang didapat di rumah atau dalam buku yang tidak dimengertinya. Sementara itu, posisi duduk sudah diatur sedemikian rupa, sehingga dari pembagian kelompok keposisi awal tidak memerlukan waktu banyak yang mengakibatkan tidak efisien. Dengan demikian, konsentrasi siswa sudah dapat dikondisikan dengan baik saat harus bagi kelompok dan kembali keposisi semula. Kekurangan-kekurangan yang ditemukan pada siklus I, sudah tidak terdapat lagi pada siklus II sehingga perhatian siswa sudah terpusat pada pembelajaran dan kondisi belajarpun semakin kondusif.

\section{PENUTUP}

Berdasarkan hasil penelitian dapat disimpulkan bahwa telah terjadi peningkatan terhadap hasil belajar. Penelitian pada pembelajaran tematik muatan mata pelajaran IPS tentang tema 4 sehat itu penting pada kelas V SDN Rawamangun 09 Pagi Jakarta Timur dengan menggunakan model pembelajaran kooperatif tipe talking stick telah menunjukkan hasil belajar yang diharapkan. Selain itu, penggunaan model kooperatif tipe talking stick menjadikan pembelajaran lebih bermakna dimana siswa selain bekerja berkelompok juga merasa senang karena belajar sambil bermain sesuai dengan karakter siswa kelas $\mathrm{V}$ yang senang berkelompok dan bermain.

Pembelajaran yang pada awalnya berlangsung hanya dengan metode ceramah, dan berlangsung hanya searah membuat siswa dan guru berada dalam pembelajaran yang tidak interaktif. Dengan keberadaan talking stick, siswa menjadi lebih interaktif dengan guru serta menambah tingkat konsentrasi siswa terhadap pelajaran karena tongkat talking stick 
diberikan kepada siswa secara acak.

Pada siklus pertama, hasil belajar siswa belum seluruhnya meningkat sedangkan pada siklus kedua, hasil belajar siswa sudah meningkat dan mencapai nilai kriteria ketuntasan minimal (KKM). Berdasarkan hasil belajar siswa yang di dapat oleh siswa menyatakan bahwa pada siklus pertama, rata - rata nilai hasil belajar sebesar 70,2\% dan meningkat menjadi 99\% pada siklus kedua. Pada siklus pertama 6 orang siswa belum mencapai nilai KKM dan pada siklus kedua 1 orang siswa belum mencapai nilai KKM.

Saran

Berdasarkan kesimpulan hasil penelitian ini maka peneliti menyampaikan saran dan sebagai berikut: (1) dalam pembelajaran tematik (khususnya mata pelajaran IPS tentang sehat itu penting) guru hendaknya mengunakan model yang bervariasi salah satunya adalah model kooperatif tipe talking stick sehingga tercipta situasi dan kondisi pembelajaran yang menyenangkan yang menyebabkan siswa termotivasi untuk belajar dan akan berdampak pada hasil belajar siswa; (2) pelaksanaan pembelajaran sebaiknya direncanakan sesuai scenario pembelajaran yang sesuai dengan karakter siswa kelas V sehingga pembelajaran akan menjadi tertib dan terarah serta tidak membosankan; (3) sebagai seorang guru Sekolah Dasar, kita diharapkan mampu menciptakan pembelajaran yang aktif, inovatif, kreatif, dan menyenangkan guna mencapai tujuan pendidikan yang diharapkan; (4) dalam pembelajaran hendaknya dapat meningkatkan kreativitas siswa; (5) penelitian ini hendaknya ditindaklanjuti oleh peneliti lain, agar dapat dijadikan bahan masukkan dalam mengembangkan aspek-aspek yang diteliti sehingga diperoleh hasil yang optimal; (6) sebaiknya pihak pendidik dapat lebih kreatif dan inovatif dalam mengembangkan metode pembelajaran, sehingga dapat meningkatkan proses pemahaman siswa dalam belajar yang pada akhirnya dapat meningkatkan hasil belajar; (7) perlu pengawasan yang seimbang untuk mengontrol interaksi individu di dalam pembelajaran kelompok agar proses belajar terarah pada hasil yang hendak dicapai; (8) sebagai referensi guru atau tenaga pendidik lainnya untuk menggunakan model pembelajaran kooperatif tipe team assisted individualization pada pelajaran yang lain; (9) guru harus membuat siswa aktif dan termotivasi belajar agar siswa semangat dalam mengikuti kegiatan pembelajaran; (10) guru hendaknya bersifat sebagai fasilitator siswa yang berfungsi memfasilitasi siswa agar siswa mandiri dan percaya diri dalam memecahkan masalahnya tanpa tergantung pada yang lain.

\section{DAFTAR PUSTAKA}

Ahmadi, A. (2003). Ilmu sosial dasar. Jakarta: PT. Rineka Cipta.

Aunurrahman. (2009). Belajar dan pembelajaran. Bandung: Alfabeta.

Hendra, S. (2005). Pembelajaran Ilmu Pengetahuan Sosial. Jakarta: UHAMKA PRESS.

Lie, A. (2007). Cooperative learning. Jakarta: PT. Grasindo.

Siregar, E. \& Hartini Nara. (2010). Teori belajar dan pembelajaran. Bogor: Ghalia Indonesia.

Sugiyanto. (2010). Model-model pembelajaran inovatif. Surakarta: Yuma Pustaka.

Suprijono, A. (2009). Cooperative learning teori dan aplikasi PAIKEM. Yogyakarta: Pustaka Pelajar.

Wardani, IGAK. \& Kuswaya, W. (2009). Penelitian tindakan kelas. Jakarta: Universitas Terbuka. 